Bangladesh J. Bot. 41(1): 35-41, 2012 (June)

\title{
WATER, SEDIMENT AND MACROPHYTE QUALITY OF SOME SHRIMP CULTURE PONDS AND FRESHWATER ECOSYSTEMS OF KOYRA
}

\author{
Abdullah Harun Chowdhury* and Roxana Ahmed ${ }^{1}$ \\ Environmental Science Discipline, Khulna University, Khulna-9208, Bangladesh
}

Key words: Macrophytes, Shrimp culture ponds, Freshwater ecosystems

\begin{abstract}
A total of 29 genera belonging to 24 families of aquatic macrophytes were recorded. Among these, 25 species were recorded from the freshwater aquatic ecosystems, 4 species from both the shrimp culture ponds and freshwater aquatic ecosystems and only one from the shrimp culture ponds. The physicochemical conditions of both the habitats indicate that very poor number of macrophytes can grow in the shrimp culture ponds due to high salinity of water and soil. Low population and abundance indicate that the macrophytes are in alarming condition in Koyra due to increasing salinity.
\end{abstract}

\section{Introduction}

Koyra is the southern Upazila of Khulna district and located between $21^{\circ} 31^{\prime} \mathrm{N}$ and $21^{\circ} 43^{\prime} \mathrm{N}$ and $89^{\circ} 14^{\prime} \mathrm{E}$ and $89^{\circ} 31^{\prime} \mathrm{E}$. Sundarbans, the mangrove forest of Bangladesh is situated in the southern part of it. Most of the lands and water bodies of this area are converted to shrimp culture ponds by canalling saline water. As shrimp is a cash crop and attracting international market with an increasing rate, intensity of shrimp cultivation is also increasing with the same magnitude. In this aquaculture practice more and more so called freshwater areas are permanently converted to saline water bodies. This is alarming because it reduces freshwater resources to the local people and changes greatly in the components of biodiversity. Among the plant communities, macrophyte population is the worst affected group because at the time of conversion of a freshwater body into a shrimp culture pond macrophytes are cleaned first. During monsoon and post-monsoon, the salinity of the shrimp culture ponds decreases to $10 \mathrm{ppt}$ when some macrophytes are seen to grow in the habitat.

So far some research work on the soil and water quality and phytoplankton abundance in the estuarine regions of the Sundarbans mangrove forests have been carried out (Ahsan et al. 2003, Hossain and Chowdhury 2008). Billah et al. (2008) studied eight water quality parameters from two freshwater shrimp culture ponds of this area. Planktonic and attached microalgal communities from the shrimp culture ponds were studied by Islam and Mannan (1986), Islam and Khundker (2003, 2004). Rahman et al. (2008) studied the diversity and distribution of aquatic weeds in and around Khulna city. Though, Khan and Halim (1987) mentioned some macrophytes from the Khulna Division no individual report on macrophytes of Koyra Upazila does exist. The present investigation has therefore been undertaken to study the macrophytes of some shrimp culture ponds and freshwater aquatic ecosystems situated in Koyra. To compare this two habitats investigation was also carried out to know the physicochemical characteristics of water and submerged sediment.

\section{Materials and Methods}

Monthly sampling from 10 permanent stations from each of shrimp culture ponds (SCP) and freshwater aquatic ecosystems was carried out from May, 2009 - April, 2011. The Unions (administrative units at village level) of Koyra holding 10 stations of shrimp culture ponds were:

*Author for correspondence: <aharunc_ku@yahoo.com>. ${ }^{1}$ Department of Botany, Jahangirnagar University, Savar, Dhaka, Bangladesh. 
Dakshin Bedkashi 5, Uttar Bedkashi 3 and Maharajpur 2 while the Unions holding 10 stations of freshwater aquatic ecosystems were: Amdi 6, Bagali 3 and Uttar Bedkashi 1. The distance among the stations was 400 - $800 \mathrm{~m}$ from each other. Water depth in them ranged from $0.7-3.2 \mathrm{~m}$. The stations of shrimp culture ponds had a surface area ranged from 1.3 - 8.5 acre and the surface area of freshwater aquatic ecosystems ranged from 0.6 - 1.7 acre.

By using a country boat, the sample of macrophyte was collected by hand (Ambasht 1990). After collection samples were carried to the laboratory under wet condition and later on preserved on herbarium sheet for identification. The populations of aquatic plants in field were measured by following quadrate method (Ambasht 1974). Water from $10-25 \mathrm{~cm}$ depth was collected for physicochemical analyses (Trivedy 1993). A standard Secchi disc was used to measure the transparency of water while for water temperature a digital thermometer was used (Model No. 950). In situ measurements of total suspended solids (TSS), total dissolved solids (TDS), conductivity, salinity, $\mathrm{pH}$, dissolved oxygen (DO), oxidation reduction potential (Eh) and oxidation reduction index $\left(\mathrm{rH}_{2}\right)$ were carried out with the help of respective portable field meters. Titrimetric methods were used to determine free $\mathrm{CO}_{2}, \mathrm{CO}_{3}$ and $\mathrm{HCO}_{3}$ alkalinities (Welch 1948). $\mathrm{BOD}_{5}, \mathrm{COD}$ and $\mathrm{NO}_{3}-\mathrm{N}$ were measured following APHA (1989). Calcium and magnesium were estimated following Mishra et al. (1992). Phosphate and silicate were measured following Gautam (1990). Shovels and large ladders were used to collect the bottom soil samples according to Trivedy (1993). Bottom soil quality was determined in the SRDI laboratory of Khulna following Jackson (1973) and Page et al. (1982). Aquatic macrophytes were identified following Khan and Halim (1987), Fassett (1960) and other relevant literatures. The identification was verified from the Bangladesh National Herbarium, Dhaka.

\section{Results and Discussion}

An average of the collected data of samples of the study stations were made and presented in tables, as their monthly and seasonal variations were negligible. The physicochemical conditions of shrimp culture ponds and freshwater ecosystems are given in Table 1 while Table 2 contains the ranges of physicochemical conditions of soil. Relative density of macrophytes is given in Table 3.

During the period of study the highest air and water temperature, transparency, TDS, conductivity, salinity, $\mathrm{BOD}_{5}$, COD, calcium, magnesium, $\mathrm{PO}_{4}$ and $\mathrm{NO}_{3}-\mathrm{N}$, and lowest value of TSS, $\mathrm{pH}, \mathrm{DO}$ and silicate were recorded in summer. Whereas the highest value of $\mathrm{pH}$ and $\mathrm{DO}$ were recorded in post-monsoon, and TSS and silicate were recorded in monsoon. The lowest value of air and water temperature, and $\mathrm{BOD}_{5}$ were recorded in winter. But the lowest value of transparency, TDS, conductivity, salinity, COD, calcium, magnesium, $\mathrm{PO}_{4}$ and $\mathrm{NO}_{3}-\mathrm{N}$ were recorded in monsoon.

During the study the variations of all elements of soil of shrimp culture ponds were negligible in the winter, monsoon, post-monsoon and summer periods. Only five aquatic plants belonging to five different families were recorded from the shrimp culture ponds. Maximum density and important value index of all recorded plants were recorded in post-monsoon, minimum in winter period and no plants were recorded in summer. The highest density and important value index were shown by Scirpus articulatus whereas the lowest density and important value index were recorded for Potamogeton pectinatus.

In ecosystems the highest air and water temperature, transparency, TDS, conductivity, salinity, $\mathrm{BOD}_{5}, \mathrm{COD}$, calcium, magnesium, $\mathrm{PO}_{4}$ and $\mathrm{NO}_{3}-\mathrm{N}$, and lowest value of TSS, $\mathrm{pH}, \mathrm{DO}$ and silicate were recorded in summer period. The highest value of DO was recorded in winter, and TSS and silicate were recorded in post-monsoon. The lowest value of air and water temperature, 
and $\mathrm{BOD}_{5}$ were recorded in winter period. But the lowest value of transparency, TDS, conductivity, salinity, COD, calcium, magnesium, $\mathrm{PO}_{4}$ and $\mathrm{NO}_{3}-\mathrm{N}$ were recorded in monsoon.

Table 1. Annual mean values $( \pm \mathrm{SD})$ of different physicochemical parameters from shrimp culture ponds and freshwater aquatic ecosystems of Koyra.

\begin{tabular}{lcll}
\hline Parameters & Units & $\begin{array}{l}\text { Shrimp culture } \\
\text { ponds }\end{array}$ & $\begin{array}{l}\text { Freshwater aquatic } \\
\text { ecosystems }\end{array}$ \\
\hline Air temp. & ${ }^{\circ} \mathrm{C}$ & $26.8(5.5)$ & $26.6(5.4)$ \\
Water temp. & ${ }^{\circ} \mathrm{C}$ & $23.7(5.4)$ & $23.4(5.2)$ \\
Secchi depth & $\mathrm{cm}$ & $20.0(4.0)$ & $22.0(7.0)$ \\
TSS & $\mathrm{mg} / \mathrm{l}$ & $95.0(39.0)$ & $46(13)$ \\
TDS & $"$ & $15826(244)$ & $1124(102)$ \\
Conductivity & $\mu$ phms/cm & $22392(465)$ & $14328(684)$ \\
Salinity & $\mathrm{ppt}$ & $12.4(3.8)$ & $0.9(0.8)$ \\
pH & & $7.9(0.2)$ & $7.2(0.4)$ \\
$\mathrm{DO}$ & $\mathrm{mg} / \mathrm{l}$ & $5.2(0.8)$ & $4.2(0.6)$ \\
Eh & $\mathrm{mv}$ & $0.861(0.028)$ & $0.921(0.017)$ \\
$\mathrm{rH}_{2}$ & & $31.71(0.16)$ & $33.13(0.22)$ \\
$\mathrm{BOD}$ & & $3.8(0.8)$ & $2.2(0.7)$ \\
$\mathrm{COD}$ & $\mathrm{mg} / \mathrm{l}$ & $62(14)$ & $23(4)$ \\
$\mathrm{CO}_{2}$ & $"$ & - & $24(23)$ \\
$\mathrm{CO}_{3}$ alk. & $"$ & $44(8)$ & - \\
$\mathrm{HCO}_{3}$ alk. & $"$ & $164(19)$ & $278(34)$ \\
$\mathrm{Ca}^{2+}$ & $"$ & $235(16)$ & $58(6)$ \\
$\mathrm{Mg}^{2+}$ & $"$ & $585(32)$ & $67(11)$ \\
$\mathrm{PO}_{4}$ & $"$ & $0.92(0.11)$ & $1.31(0.43)$ \\
$\mathrm{Silicate}^{2+}$ & $"$ & $1.49(0.35)$ & $1.77(0.41)$ \\
$\mathrm{NO}_{3}$-N & $"$ & $3.32(0.23)$ & $2.63(0.12)$ \\
\hline
\end{tabular}

During the period of study the variations of all elements of soil were negligible in the winter, monsoon, post-monsoon and summer. Total 29 aquatic plant species belonging to 23 families were recorded during the study period from the freshwater ecosystems. The maximum populations of plants were recorded in post-monsoon and minimum in summer. The highest density was recorded for Lemna perpusilla in the freshwater ecosystems but the highest important value index was recorded for Ludwigia adscendens (Table 3). The lowest density and important value index in the freshwater ecosystems were recorded for Potamogeton pectinatus.

The yearly mean values of water temperature, TSS, TDS, $\mathrm{pH}, \mathrm{BOD}_{5}, \mathrm{COD}$, calcium, magnesium and $\mathrm{NO}_{3}-\mathrm{N}$ of shrimp culture ponds were always higher than those of freshwater ecosystems. The recorded mean values of transparency, oxidation reduction potential, oxidation reduction index and $\mathrm{PO}_{4}$ of shrimp culture ponds were always lower than those of freshwater ecosystems (Table 1). Soil of shrimp culture ponds is always alkaline in nature. Soil $\mathrm{pH}$, salinity, calcium and magnesium values of shrimp culture ponds are always higher than those of freshwater ponds. Salinity of water and soil of freshwater ponds was recorded during dry season as that time the volume of water in these ecosystems was very poor as well as in that time freshwater ecosystems become saline due to subsurface leaching of saline water from the shrimp culture ponds. The abundance and important value index of macrophytes of freshwater ecosystems except 
Ruppia maritima, Scirpus articulatus and Typha elephantina showed significant (5\% level) negative co-relation with TDS $(-0.935)$, salinity $(-0.929), \mathrm{BOD}_{5}(-0.878)$, COD $(-0.866)$, oxidation reduction potential $(-0.850)$, calcium $(-0.839)$ and magnesium $(-0.820)$. The abundance and importance value index of macrophytes except Potamogeton pectinatus of shrimp culture ponds were found to have significant (5\% level) positive correlations with TDS (0.844), salinity (0.840), calcium (0.824) and magnesium (0.810) values which indicate that the increasing pattern of abundance of macrophytes of shrimp culture ponds are fully depending on the increasing pattern of TDS, salinity, calcium and magnesium values.

Table 2. Chemical conditions of bottom soil of the shrimp culture ponds and freshwater ecosystems of Koyra.

\begin{tabular}{|c|c|c|c|}
\hline Parameters & Units & $\begin{array}{l}\text { Shrimp } \\
\text { culture ponds }\end{array}$ & $\begin{array}{l}\text { Freshwater aquatic } \\
\text { ecosystems }\end{array}$ \\
\hline $\mathrm{pH}$ & & $7.4-8.3$ & $6.9-8.0$ \\
\hline Salinity & ppt & $7.6-15.9$ & $0.4-1.8$ \\
\hline Organic matter & $\%$ & $1.26-1.29$ & $1.65-1.88$ \\
\hline Calcium & meq/100 g soil & $40.70-51.00$ & $28.50-30.00$ \\
\hline Magnesium & $"$ & $4.68-6.44$ & $2.32-2.47$ \\
\hline Potassium & $"$ & $0.14-0.19$ & $0.10-0.12$ \\
\hline Total nitrogen & $\%$ & $0.13-0.21$ & $0.06-0.08$ \\
\hline Phosphorus & $\mu \mathrm{g} / \mathrm{g}$ soil & $2.40-2.60$ & $2.53-2.87$ \\
\hline Sulfur & $"$ & $23.20-23.84$ & $20.14-20.38$ \\
\hline Boron & " & $0.14-0.19$ & $0.11-0.16$ \\
\hline Copper & " & $3.40-3.73$ & $2.82-3.15$ \\
\hline Iron & $"$ & $24.12-24.69$ & $23.94-24.13$ \\
\hline Manganese & " & $7.50-8.00$ & $7.10-7.40$ \\
\hline Zinc & " & $0.91-0.98$ & $0.84-0.89$ \\
\hline
\end{tabular}

During the period of study, only four macrophytes - Potamogeton pectinatus, Ruppia maritima, Scirpus articulatus and Typha elephantina were common in shrimp culture ponds and freshwater ecosystems; but the abundance and important value index of these plants of the freshwater ecosystems were always lower than those of shrimp culture ponds (Table 3). Zannichellia palustris showed significant (5\% level) positive co-relation with TDS (0.898), salinity (0.886) and calcium (0.859). Zannichellia palustris was recorded only in the shrimp culture ponds and which is indicating that this plant only can grows in saline habitats. Sahai and Srivastava (1976), Kulshreshtha and Gopal (1981), Kulshreshtha (1982), Purohit and Singh (1985), and Pip (1987) observed in their studies that Ceratophyllum sp., Limnophylla heterophylla, Ludwigia sp., Marsilea quadrifolia, Nymphoides sp., Ottelia sp., Pistia sp., Salvinia sp. and Utricularia sp. can grow only in freshwater. As per the works of Sahai and Srivastava (1976), Kulshreshtha and Gopal (1981), and Kulshreshtha (1982) the present freshwater ecosystems were almost free from salinity during the period of study except two sampling spots in the month of March and April. The salinity of these sampling spots was found to vary from 0.6$2.5 \mathrm{ppt}$ and mean value was $0.9 \pm 0.8 \mathrm{ppt}$. The recorded abundance and important value index of the freshwater macophytes were poor in these two freshwater ecosystems.

The physico-chemical conditions of both the aquatic ecosystems and the recorded macrophytes indicate that very poor number of macrophytes can grow in the shrimp culture ponds 
due to high salinity of water and soil but the freshwater ecosystems are rich with different types of macrophytes. The findings of the present study also indicate that the saline water ecosystems are not suitable for freshwater macrophytes as during the period of study, out of 29 freshwater macrophytes only 4 were recorded in shrimp culture ponds (Table 3). Present findings also indicate that only monocotyledon plants can grow in the shrimp culture ponds, whereas 11 dicotyledons, 16 monocotyledons and 2 pteridophytes were present in the freshwater ecosystems.

Table 3. Relative density and importance value index of hydrophytes occurring in the shrimp culture ponds and freshwater ecosystems of Koyra.

\begin{tabular}{|c|c|c|c|c|c|}
\hline \multirow[b]{2}{*}{ Plants } & \multirow[b]{2}{*}{ Family } & \multicolumn{2}{|c|}{$\begin{array}{l}\text { Shrimp culture } \\
\text { ponds }\end{array}$} & \multicolumn{2}{|c|}{$\begin{array}{l}\text { Freshwater } \\
\text { ecosystems }\end{array}$} \\
\hline & & $\begin{array}{c}\text { Relative } \\
\text { density } \\
(\%)\end{array}$ & $\begin{array}{l}\text { Importance } \\
\text { value index }\end{array}$ & $\begin{array}{c}\text { Relative } \\
\text { density } \\
(\%)\end{array}$ & $\begin{array}{l}\text { Importance } \\
\text { value index }\end{array}$ \\
\hline Aponogeton undulatus Roxb. & Aponogetonaceae & - & - & $2.32-4.55$ & $32.26-51.96$ \\
\hline Bergia capensis L. & Elatinaceae & - & - & $2.45-4.14$ & $36.54-60.30$ \\
\hline Ceratophyllum demersum L. & Ceratophyllaceae & - & - & $5.34-7.58$ & 68.14-99.02 \\
\hline Cyperus platystylis R. Br. & Cyperaceae & - & - & $6.92-7.46$ & 54.21-76.09 \\
\hline $\begin{array}{l}\text { Eichhornia crassipes (Mart.) } \\
\text { Solms }\end{array}$ & Pontederiaceae & - & - & $5.17-7.27$ & 83.22-107.84 \\
\hline Enhydra fluctuans Lour. & Compositae & - & - & $6.11-8.53$ & $77.69-86.42$ \\
\hline Hygroryza aristata (Retz.) & Gramineae & - & - & $2.22-4.06$ & $30.63-58.70$ \\
\hline Ipomoea aquatica Forsk. & Convolvulaceae & - & - & $3.28-4.65$ & 71.92-82.12 \\
\hline Lemna perpusilla Torrey. & Lemnaceae & - & - & $8.86-14.48$ & 65.49-97.39 \\
\hline $\begin{array}{l}\text { Limnophylla heterophylla } \\
\text { Roxb. Benth }\end{array}$ & Scrophulariaceae & - & - & $3.05-5.48$ & 43.54-69.58 \\
\hline $\begin{array}{l}\text { Ludwigia adscendens (L.) } \\
\text { Hara. }\end{array}$ & Onagraceae & - & - & 7.43-9.70 & 88.34-119.82 \\
\hline Marsilea quadrifolia L. & Marsileaceae & - & - & $5.67-8.16$ & $74.66-114.47$ \\
\hline $\begin{array}{l}\text { Monochoria hastata (L.) } \\
\text { Solms }\end{array}$ & Pontederiaceae & - & - & $4.43-7.70$ & 68.34-99.45 \\
\hline Najas graminea Del. & Najadaceae & - & - & $2.51-4.47$ & 38.34-57.59 \\
\hline Nymphaea nouchali Burm. f. & Nymphaeaceae & - & - & 4.66-6.18 & $68.50-94.74$ \\
\hline N. stellata Willd. & Nymphaeaceae & - & - & $2.57-4.12$ & 31.86-64.85 \\
\hline Nymphoides cristatum (Roxb. & )Menyanthaceae & - & - & $2.69-4.56$ & $30.48-61.14$ \\
\hline Oryza rufipogon Griff. & Gramineae & - & - & $2.05-4.34$ & 23.32-39.19 \\
\hline Ottelia alismoides (L.) Pers. & Hydrocharitaceae & - & - & 2.42-3.98 & $67.45-82.27$ \\
\hline $\begin{array}{l}\text { Paspalidium punctatum } \\
\text { (Burm.) A. }\end{array}$ & Gramineae & - & - & 2.14-3.82 & $31.75-43.30$ \\
\hline Pistia stratiotes L. & Araceae & - & - & $5.49-7.56$ & $60.94-82.38$ \\
\hline Polygonum glabrum Willd. & Polygonaceae & - & - & $3.71-5.15$ & $47.42-76.64$ \\
\hline Potamogeton pectinatus L. & Potamogetonaceae & $1.46-2.22$ & 31.18-35.44 & $1.20-1.84$ & 26.74-29.67 \\
\hline Ruppia maritima L. & Ruppiaceae & $2.93-5.26$ & 58.64-65.98 & $1.86-2.82$ & $27.56-32.48$ \\
\hline Salvinia natans willd. & Salviniaceae & - & - & $2.12-4.28$ & $39.27-47.65$ \\
\hline Scirpus articulatus L. & Cyperaceae & $9.58-19.26$ & $75.72-121.44$ & $3.41-6.38$ & $35.62-56.11$ \\
\hline $\begin{array}{l}\text { Spirodela polyrhiza (L.) } \\
\text { Schleid. }\end{array}$ & Lemnaceae & - & - & $5.24-8.52$ & 38.69-63.34 \\
\hline Typha elephantina Roxb. & Typhaceae & $2.86-4.64$ & $38.27-47.16$ & 2.04-3.92 & $32.29-41.85$ \\
\hline Utricularia aurea Lour. & Lentibulariaceae & - & - & $1.42-2.38$ & 26.63-34.72 \\
\hline Zannichellia palustris L. & Zannichelliaceae & $4.72-10.97$ & 59.88-116.14 & - & - \\
\hline
\end{tabular}

-, Not determined. 
Out of 30 species 25 can grow only in the freshwater of Koyra area. Almost similar macrophytes were recorded from freshwater ecosystems by Bala and Mukherjee (2007), Rahman et al. (2008), Sasmal et al. (2009) and Panda et al. (2009) in their studies. But the abundance and important value index of the recorded freshwater macrophytes of Koyra are lower than the findings of Rahman et al. (2008). Rahman et al. (2008) worked in the freshwater ecosystems beside the Khulna city area where yearly mean value of TDS was lower than $700 \mathrm{mg} / \mathrm{l}$ but the yearly mean value of TDS of Koyra was more than $1000 \mathrm{mg} / \mathrm{l}$. No macrophytes were recorded by Islam and Hossain (1979), Islam and Mannan (1986), Karim and Islam (2003), Ahsan et al. (2003), Islam and Khundker (2003, 2004). Hossain and Chowdhury (2008), Billah et al. (2008), Sharmin and Alam (2009) and Khanam et al. (2009) in their studies. The results of recorded freshwater macrophytes of Koyra indicate that the number of population and abundance of the study area macrophytes may be affected due to decreasing of freshwater ecosystems for further extension of unplanned saline water shrimp culture practices. Day by day TDS and salinity are increasing in freshwater ecosystems in the coastal area due to subsurface leaching of saline water from shrimp culture ponds (Ahsan et al. 2003, Sasmal and Choudhury 2009), which is alarming for freshwater macrophytes.

Utricularia aurea, Nymphaea stellata, Nymphoides cristatum and Oryza rufipogon may become vulnerable in the study area due to degradation of their habitats by increasing salinity. According to Pandit (1984) and Karim (1993) all macrophytes should be conserved in their own habitats. So, it is necessary to conserve the freshwater macrophytes of Koyra. A sustainable management plan such as area demarcation is necessary for the saline water shrimp culture (Karim and Islam 2003) to protect the further degradation of the existing freshwater plant diversity of the study area. The results of this study will be helpful for further study and sustainable management plan of the hydrophytes of saline affected areas.

\section{Acknowledgements}

The authors acknowledge the partial research support from the University Grants Commission of Bangladesh and the Bangladesh National Herbarium for proper identification of aquatic macrophytes.

\section{References}

Ahsan M, MR Bhuiyan, SN Biswas and TS Kumar 2003. Soil and water characteristics in the eastern part of the Sundarbans. In: The Sundarbans, the Largest Mangrove Forest on the Earth: A World Heritage Site (Murtaza, M.G. eds.), pp. 144-152. Khulna University, Bangladesh.

Ambasht RS 1974. Plant Ecology. Students' Friends and Co., Varanasi, India. 261 pp.

Ambasht RS 1990. Environment and Pollution. Students' Friends and Co., Varanasi, India.

APHA 1989. Standard methods for the examination of water and waste water. American Public Health Association, Washington. 1125 pp.

Bala G and A Mukherjee 2007. Useful plants of Wetlands in Nadia district, West Bengal. Geobios (Jodpur) 34(4): 253-256.

Billah SM, S Nasrin, KR Iqbal and MA Uddin 2008. Water quality parameters in shrimp culture system of Khulna region. South Asian J. Agric. 3(1\&2): 61-66.

Fasset NC 1960. A Manual of Aquatic Plant. The University of Wisconsin Press, Madison. 405 pp.

Gautam A 1990. Ecology and Pollution of Mountain Water. Ashish Publ. House, New Delhi, India. 209 pp.

Hossain MZ and AH Chowdhury 2008. Phytoplankton abundance in relation to physico-chemical conditions of the Sundarbans estuary. J. Asiat. Soc. Bangladesh (Sci.) 34(2): 103-112.

Islam AKMN 1973. The algal flora of Sundarbans Mangrove forest. Bangladesh J. Bot. 2(2): 11-36. 
Islam AKMN and J Khundker 2003. Algal flora of brackishwater shrimp-culture ponds at Khulna, Bangladesh-I. Cyanophyceae. Bangladesh J. Plant Taxon. 10(2): 57-71.

Islam AKMN and J Khundker 2004. Algal flora of brackishwater shrimp-culture ponds at Khulna, Bangladesh-II. Cyanophyceae. Bangladesh J. Plant Taxon. 11(1): 69-76.

Islam AKMN and MA Mannan 1986. Algal flora of some brackish water shrimp culture ponds at Satkhira. Dhaka Univ. Stud. Part E 1(1): 7-18.

Islam AKMN and M Hossain 1979. Preliminary study in the algal flora of Bagerhat, Khulna. J. Asiatic. Soc. Bangladesh (Sci.) 5(1): 37-45.

Jackson ML 1973. Soil Chemical Analysis. Prentice Hall of India Pvt. Ltd. New Delhi, India.

Karim A 1993. Plant diversity and conservation in freshwater wetlands. In: Freshwater Wetlands in Bangladesh: Issues and Approaches for Management (Nishat A, Z Hussain, MK Roy and A Karim Eds), pp. 75-99. IUCN.

Karim MR and KS Islam 2003. Shrimp culture around the Sundarbans and its effects on land, agriculture, livestock and poultry of Rampal, Bagerhat. In: The Sundarbans, the Largest Mangrove Forest on the Earth: A World Heritage Site, Murtaza MG (Ed), pp. 18-24. Khulna Univ., Bangladesh.

Khan MS and M Halim. 1987. Aquatic Angiosperms of Bangladesh. BARC, Dhaka. 120 pp.

Khanam M, AK Ghosh, SK Biswas and MW Sabbir 2009. Comparative study of target and non-target aquaculture products of shrimp farm in Satkhira district, Bangladesh. South Asian J. Agric. 4(1\&2):1419.

Kulshreshtha M 1982. Comparative ecological studies on two species of Ceratophyllum. Proc. 6th EWRS Int. Symp. Aquatic Weeds, Novi Sad: 29-36.

Kulshreshtha M and B Gopal 1981. Effect of sewage pollution on growth of two aquatic macrophytes. Acta Limnol. Indica 1: 19-24.

Mishra SN, R Swarup and VP Jauhari 1992. Encyclopaedia of Ecology, Environment and Pollution Control. Environmental Air and Water Analysis. Vol. 17. Ashish Publ. House, New Delhi, India.

Page AL, RH Miller and DR Keeney. 1982. Methods of Soil Analysis (Part-2). American Society of Agronomy, Madison, Wisconsin, USA.

Panda S, D Bhattacharyya and PK Mukherjee 2009. Macrophytic vegetation of wetlands of West BengalSome case studies: Perspectives of Conservation. J. Econ. Taxon. Bot. 33(3): 643-656.

Pandit AK 1984. Role of macrophytes in aquatic ecosystems and management of freshwater resources. J. Environmental Management 18: 73-88.

Pip P 1987. The ecology of Potamogeton in central North America. Hydrobiologia 153: 203-216.

Purohit R and SP Singh 1985. Submerged macrophytic vegetation in relation to eutrophication level in Kumaun Himalaya. Environ. Pollut. Ser. 139: 161-173.

Rahman SMB, S Kumar, MAB Sayeed, MW Sabbir, AFMHasanuzzaman, MI Alam and MG Sarower 2008. Ecological diversity and distribution of aquatic and semi-aquatic weeds in Khulna district, Bangladesh. South Asian J. Agric. 3(1\&2): 163-168.

Sahai R and VC Srivastava 1976. The physicochemical complexes and its relationship with the macrophytes of Chilwa lake. Geobios. 3: 15-19.

Sasmal B, K Kanta and AK Mondal 2009. Aquatic angiospermic plants of Purba Medinipur district, West Bengal with reference to their sustainable use. Envi. Ecol. 27(2A): 733-737.

Sasmal SK and A Choudhury 2009. Seasonal variation of limnological parameters in the coastal West Bengal, India. Envi . Ecol. 27(3A): 1253-1257.

Sharmin A and KMM Alam 2009. Practice of Aquasilviculture at Koyra upazila in Khulna district. South Asian J. Agric. 4(1\&2):51-54.

Trivedy RK 1993. River Pollution in India. Ashish Publ. House, New Delhi, India. 294 pp.

Welch PS 1948. Limnological Methods. McGraw Hill Book Company, New. York. 381 pp.

(Manuscript received on 1 November, 2011; revised on 17 March, 2012) 